\title{
Healthy Aging: Education, Health, Health Psychology and Leisure
}

\author{
Juan Juan Mouriño Mosquera1, Claus Dieter Stobäus ${ }^{2}$ \\ ${ }^{1}$ Postgraduate Programs in Education, Pro-Rectory of Postgraduateand Research, Pontifical Catholic University \\ of Rio Grande do Sul, Porto Alegre, RS, Brazil \\ ${ }^{2}$ Postgraduate Program in Education and in Biomedical Gerontology, Pontifical Catholic University of Rio \\ Grande do Sul, Porto Alegre, RS, Brazil \\ Email: Stobaus@pucrs.br
}

Received 11 April 2016; accepted 17 June 2016; published 21 June 2016

Copyright (C) 2016 by authors and Scientific Research Publishing Inc.

This work is licensed under the Creative Commons Attribution International License (CC BY).

http://creativecommons.org/licenses/by/4.0/

(c) () Op Open Access

\section{Abstract}

In the recent years, we are seeing the aging of global population with transformations of growth curves, demands in the areas of Health, Psychology and Education, in particular addressing the better global preparedness for this healthy aging. Positive Psychology has been taking ground, with interfaces with Health Psychology, Education for Leisure and Recreation, Emotional Education and lifelong Health Promotion, connecting with areas that can be applied by professionals called educators and caregivers, assisting the human development from the point of view of higher life quality, especially the one connected to human development along adulthood, beginning at the end of adolescence and going until the death. After reading authors from these areas, as Seligman, Snyders, López, Ballesteros, Carr, Adrián, Baltes, Hué, Gardner, Goleman, Jesus, we see the alert for a performance and decision-making throughout life, toward the knowledge of how we work and we can improve our outsourcing behaviors and healthier way of improving the way of dealing better with emotions, the so-called Emotional Education, within the context of Neuroscience, as well as aspects of education and promotion for implications with health, leading to what we consider an Emotional Education, Health Education and Welfare.

\section{Keywords}

Education, Health, Health Psychology and Leisure

\section{Introduction}

In the last decades of the twentieth century and early twenty-first, it has broadened the interest in the themes of 
Adulthood in terms of Human Development Lifelong (Lifespan approach), especially of late adult, to other authors considered as the elderly or elderly adult, for example by Alaphilippe \& Bailly (2014).

In addition, Seniors Education acquires great importance given the increased life expectancy, longevity and better quality of life for people worldwide.

Health is also in this sense, the focus of studies around the world, especially in developing countries, interested in improving the quality of its citizens, say Alaphilippe \& Bailly (2014).

With the perspective of the human being to reach between 110 and 120 years of life in these next 20 - 25 years, Fernández-Ballesteros (2009a, b) says; the need for us to be more prepared is evident, considering since from the aging person's point of view also for the ones who prepare themselves to take care of them and make them accompany either personal/familiarly or professionally; these aspects are also highlighted on the same way by Marchand (2005).

The Health Psychology and Positive Psychology are challenging our view knowledge and propose new ways of behaving, advancing the understanding of how human beings are headed for better construction of a new world.

These exposed themes here are briefly a major design challenges and problems akin to a way of seeing an interdisciplinary, so necessary is the expansion of knowledge, skills and attitudes in these new fields of knowledge, as described previously by (Mosquera, \& Stobäus, 1984). It's worth to remember that a research with a more critical posture, as already has been emphasized by Carr (1996) for several years, leads to better data acquisition and its applicability.

We would also like to draw your attention that these issues were the subject of our studies in our academic life since 1976, especially after the 90s, throughout discussions at scientific meetings, and the corresponding publications, as we shall see later on.

\section{About the Development of Human Being}

As cited by Fragoso \& Chaves (2012, p. 17), Cicero said that [...] the nature endows each age own qualities. Hence, the weakness of children, the impetus of young people, adults and the seriousness maturity of old age are natural things that we appreciate each of your time.

Azeredo (cited Fragoso \& Chaves, 2012: p. 283) draws attention that normal physiological aging is a process that begins with the human life and extends throughout its existence.

Authors in the field of Biomedical Gerontology, as Stobäus, Almeida, \& Resende (2014) \& Neri (2006) highlight the approach called Lifespan Approach, formulation by researchers from the Max Planck Berlin Institute, especially Baltes and his wife, with applications just to the area of the late human development. In this area of knowledge, aging is a process that occurs throughout life, whether understood as the very first cell division, at birth, immediately after the entry of the adolescence or young adulthood. Also after 60 - 65 years chronological age, due to biological factors or environmental interventions throughout life, and it may be by free radicals or oncogenes, or stressor processes of biological, psycho-emotional and social, among other theories that try to explain.

We have argued that the understanding of aging, regardless of their approach, does not occur in a stage of life, but must be understood as a continuous process that runs through all stages of human life. It could also be understood in crossovers, such as age chronological linked to date of birth (but how to understand this today with humans born even before the $4 / 5$ messes gestational age?), Or the functional age (SUM chronological with the physical, psychological development, educational, philosophical, spiritual), as they say Argimon, Esteves, Cerutti, Mosquera, \& Stobäus (2015). Another can be seen in approaches with stages of life and a broader sense, corresponding to cycles, such as spring, summer, autumn and winter (Stobäus \& Mosquera, 2014).

Now we would ask us: how many children, youth, adults are within a late adult, an elderly? It is not unreasonable, it is the "theater of the world" in which he lives, each of us lives or will live. Thus, the present, past and even the future are and contains traces of our existence, contemplating and we can look through narratives, which gives meaning to live and contemplate on life, for example when we think about the life of teachers but it could also be the other "caregivers of human beings” (Mosquera, Stobäus, \& Huertas, 2015).

The life cycle has been studied by several other authors, who have excellent concepts that help us to comprehend the direction and sense that every human being is willing to give his life, and that other humans observe and comment on it, or even to assess and it intervenes, as the Health professionals. 
So, we can say that good preparation and structuring characterize childhood and adolescence, which have been studied as a basis for all human life. They have not lost their value or their significance. We would also explain the late adult. Alaphilippe \& Bailly (2014, p. 12). Discuss very appropriately the terminology used when out that the age group is now a group within which cohabit several generations, having appeared several terminologies to describe.

And it still continue, from the '70s, the appearance of senior clubs gave rise to the term' third age 'referring to active people practicing an essentially recreational activity.

There are quite interesting considerations that the French authors do about the sexagenarian who are divided between senior and retired. The elderly as such appear from the seventies and eighties. In Biomedical Gerontology another concept for the elderly from 90 years, is that would be long-lived.

Since our design is closer to explicit by Papalia \& Feldman (2013).

Late Adult, in our view, does not abandon the characteristics of Adulthood. As understood in the two centuries have seen, that there was an increase in both the perspectives of life, better health, and especially cognitive, affective and socio-emotional dimensions.

The reflections that here accompanied us and to position ourselves at an old adult/adult late healthier and more confident in themselves and their future and preparing for an intergenerational relationship less authoritarian and extending the life cycle as more respectful of life and learning by Emotional and Cognitive Education.

We also highlight that life is, or should be, a constant and deep reflection on our own self and its configuration, as well as aspects of self-image and self-esteem that help us to better distinguish the real world and the imagined world, in the sense that we have these two very realistic elements and undistorted, to always have lifelong symbolic representations closer than is the reality in which one lives (than fantasy or an unreal world) in any stage of life, as highlighted by Mosquera \& Stobäus (2006a), Mosquera, Stobäus, Jesus, \& Herminio (2006); Dohms, Stobäus, \& Mosquera (2012). We also highlight here the idea that we are, as educators and caregivers, besides being probably in a purely cognitive level more developed, affective and social models, it is; not only cognitive one (Fontoura, Stobäus, \& Mosquera, 2011).

The life cycle can not be consolidated only with the appearance of chronological age, it is much larger and also incorporates elements such as feelings, which also lead to the construction of a care of yourself, lifelong, despite ups and downs and constant resizes before frustrations and longings (Mosquera, Stobäus, \& Timm, 2009), of developing personal qualities such as resilience (Timm, Mosquera, \& Stobäus, 2008; Sousa, Miranda, Lara Nieto, \& Pain, 2014; Sousa, 2006; Sousa \& Rodrigues Miranda, 2015). Below we analyze some elements of Emotional Education of Adults, which represent the Psychology of Health and Positive Psychology today and how they can help us to open horizons for a richer and more promising existence.

\section{Human Development and Education}

Before you begin to address the education issue in Adulthood, we will make some comments on what Alaphilippe \& Bailly (2014) call the Subjective Age. They claim that it is defined as the felt age (how we feel). Somehow, try to answer the question of what we weigh ourselves, deep down, that old feel we have it?

In a way this attitude of subjective age has connection with functional age previously mentioned. What really feel and real as possible perception we have of ourselves as a person at a time to elapse sometimes slowly, sometimes very quickly, in a given culture and environment in which we operate and in which (inter) operate, increasing (or decreasing/reducing) our (inter) relations with others. That is why we have to give account of our experiences in the world, at any stage of development. However, it seems that these elements become more present and acute with the aging and the proximity of our terminal illness.

These reflections, which even border on a more philosophical side (Mosquera \& Stobäus, 2012), but that in time all we trying to accomplish, which leads to what some authors call maturity (mature moments of life). This process has, in fact, very linked to the ongoing process of personal self-education, which can be more complex and deep with the help of a more consistent education and valued by the person. Not exactly the years of formal schooling or achieved degree, but the real value we give to the educational process as a whole, all the time, in its various aspects and interwoven levels.

It is also important to stress as highlighted by Fragoso \& Chaves (2012), a Senior Education would be an education for a society increasingly aging and more aged, with this increased longevity and better quality of life of late adults/elderly, and allowed them to live better for environments with greater preparation and care and more prepared caregivers, he is, or should be, preparing for this and at this stage a lifelong and life. Here comes 
another vision, an intergenerational education, with each learning from the other. It is distinct from the initial stage of life, which is more about teaching (and supervising, evaluating/intervening) others learn.

At the same time it must be remembered that the late adult/elderly you some missions that are different as we perceive them: to prepare itself for a more authentic self-realization, find a real meaning to your life and existence, by ending is with others in a sense of being human. This is quite distinct from "pre-determined missions" in some families or companies, for example when it says and even requires that late adults take care of the grandchildren, are the materials providers of younger until well late in their lives, let them adult children living with you and "yoke", among others.

Of course, that person and probably spent his whole life 'teaching' their family and people close to you should you "caring and loving", often imposing a choice of who will from early on the one hand, and 'pressing sentimentally' that if you do not, is not a good son/daughter.

Opposing a little this reflection, Fragoso \& Chaves (2012, p. 23) state that education for aging is a permanent way of development and individualizing significance and collective reverting for education throughout life, for education the life and healthy life. It also highlights this point of view on the development of old March and (2005).

The learning process is then basic in human life and is manifested in his actions (his experiences lifelong), both in their cognitions and in their ideas, concepts, thoughts and motor actions and feelings, feelings and emotions (Mosquera \& Stobäus, 2006b), not only in the area of education and health, but extends to all aspects of one's life.

As we can see, a late adult/elderly should seek to integrate, according to these authors, these elements together, emotion, cognition and action in diverse and different situations in which streamline and perform both individual tasks and collectively, going to the daily meeting and reality as a senior.

That said, we reiterate that in the XXI century Education should not fail to have a Humanistic-Existential nature, even with the numerous technological advances that it should also incorporate and to use, leading to Health Education (Mosquera \& Stobäus, 1984), Health Psychology and Positive Psychology.

After the great dissemination of the UNESCO report (1996/2010), Education, a Treasure to be discovered, it waqs highlighted a whole panorama for all human beings, regardless of race, creed, color, status, gender or age can learn and change If that person who is able and wants to be, learning to through their integration into humanity through appropriate educational environments and rich in stimuli, with the mission to raise awareness of their feelings and values/attitudes, along with their cognitions.

\section{Health Education and Positive Psychology}

As our purpose is to address the healthy human aging, we could not stop talking about Health Education, almost twin sister of Health Psychology.

In terms of Health Education (Mosquera \& Stobäus, 1984: p. 9) since we said what we now have as the interdisciplinary field of Health Psychology:

Health Education, we believe, is an attempt to unite the education with the medical and support in areas of knowledge such as cultural anthropology, receive enhanced Institutional Sociology and General Sociology, and enter the field of Social Psychology and Development.

We can also add (Mosquera \& Stobäus, 1984: p. 9):

What would aim at Education for Health? In our view seeks a level of healthy person, both physically, psychologically, and socially. Not only the person as an individual thing, but regarded as representative of a group and of a whole. A person's health is the health of the institutions. To the extent that people have better health. Both physical, mental and social, it seems that companies tend to be more fair, balanced and consistent.

These words written several years ago still remain important, especially in its interdisciplinary sense.

Lima, Bernardes, \& Marques (2014, p. 14) undermine the importance of social representations, as well as the influence of psychosocial factors in the assessment and treatment by health professionals' pain, but also the experiences of pain and functional disability associated.

Thus, both health aspects such as the disease are contemplated as an important dialectic to the development of the personality of a person to his late adulthood, through these social representations that are configured in ways 
of thinking and acting, have emotions and know manage them in a society so quick adjustments and continuous changes.

So, we can see that human existence would be in fact a construction that relies heavily on our senses, values and meanings that represent the world and we develop.

Finally, health is also a privilege, in a way; we should try to develop through a Psychology (more) positive, also highlighted by Snyder \& Lopez (2009). This area, in recent years, has tried to advance knowledge and actions, emphasizing what is best in each person. You must, then, be happy (or have more often happiness moments), always seeking personal growth in social, meaningful and appreciation of our journey and the others.

Another part of this approach is contemplated by Hue (2012) when he says that "the teacher well-being lies in the development of skills and leadership is teaching health guarantee", moving more negative thoughts to positive. The powers would be self-knowledge, self-esteem, emotional control, motivation, (re) knowledge of others, appreciation of others and leadership.

Also, it is worth to remember works in the field of Health Psychology that are directly related to the education, through elements such as the malaise/wellness of the teacher and work with their management and evaluation, which can be matched directly with the Health area (Zacharias, Mendes, Lettnin, Dohms, Mosquera, \& Stobäus, 2011; Stobäus, Mosquera, \& Santos, 2007; Jesus, Mosquera, Stobäus, Sampaio, Rezende, \& Mascarenhas, 2011).

\section{Aging, Positive and Affection Psychology}

As we have said, the way we view aging is understood as a process that lasts a lifetime, but during adulthood the person is late adult call, common healthy aging from the perspective of Health and Positive Psychology.

André (2014, pp. 18-19), answering about the question’? What is Positive Psychology', said:

It is simply the study of what works well in the mind of the human being, the study of mental and emotional skills that help us enjoy life to solve problems and overcome adversity. It is working in the cultivation $d$ our optimism, confidence, gratitude, [...].

And the same author follows: Positive Psychology rests on three concepts: it is a belief, an experience and a practice.

As we understand, conviction implies on knowledge of cognitive-affective nature, extending our way of seeing life and feel it the deepest and most sincere way.

In the sense of experience, it is the sought scientific validation. They are only good feelings, but also of good arguments, clinical studies. The biological, neuroscience and neuroimaging findings and carried out by studies of the brain and its consequences in contemporary societies.

As pointed out by Seligman (2005, p. 410), the progress of Positive Psychology is the validations and intervention.

Following André (2014), certain rules to implement the Positive Psychology are:

a) the important thing is I do not know what-(have the practice of happiness not just theory);

b) there is no happiness without sweat?-Strive without making efforts to see the best side of life and trying all the time which is help yourself and others;

c) persevere-in a way to persevere is not only to continue our behavior to achieve consistency and pursuit of happiness, while in a real way, we understand the problem of the contingencies of life;

d) the rope and the wires-the exercise of Positive Psychology obey what is called the string of logic, composed of a wired crowd. Alone are fragile to lift weights, but twisted turn into a rope capable of lifting and towing weights 'pretty heavy' as unhappiness. These exercises help to seek happiness and our own personal balance and socio-professional.

e) a place for unhappiness-Positive Psychology is not intended to prevent us feel, ourselves, as a being completely unhappy, which would be a bit too realistic, since happiness and unhappiness are part of human life. She is interested in resilience, the means with we face the suffering and how to apply them.

We seek to be at peace with our own existence and understand the need to accept that in our lives appears all kinds of experiences and be prepared for runs through them.

Finally, it is important to understand that happiness, in reality the moments of happiness in our lives, both individually and collectively, are the great of Positive Psychology study object. 
But we can not forget that happiness should not serve to obscure/dark adversity, since both are part of existence as a whole.

\section{Affectivity and Health}

Fragoso, \& Chaves (2012: p. 55) state that the human being's life is filled with inner experiences, thoughts, feelings, is an immensity such that we can not describe in a few words. The thrill of life for humans and the etymological root means movement.

As for Damasio (2003), the feeling is a relatively stable mental process resulting emotion.

Fragoso \& Chaves (2012, p. 67) tells us that in old age, the elderly person can get even die of loneliness when you do not feel loved, because the affection has a protective function against the adversities of life.

Thus, following this thought, the authors (Fragoso \& Chaves, 2012: p. 68) point out that the affections value all that is in and out of us, as the facts and events, as well as their subjective causes.

Lemaire \& Bherer (2012, p. 33) show us an interesting picture and leave in his preface from questions that make us meditate:

The images we have of the elderly, described by the poets or the result of our experience, correspond to the reality of aging?

These images have changed over time?

Will they evolve with scientific discoveries about aging?

To what extent these images affect our attitudes, individual and collective, for the elderly?

And yet, we know exactly about the reality of psychological aging?

Let us recall here the programs in which it intervenes in attitudes considered more negative, preparing for more positive attitudes towards life and possible overruns as Patrocinio \& Pereira (2013).

Or even Adrián (1999) perspective, for a better understanding of how the complex tangle of development in combination of cognitive, affective and emotional and socio-cultural as well as action to reduce the difficulties of development or in difficulties learning themselves (Dohms, Lettnin et al., 2014).

\section{Practices in Human Development, Education, Health Education, Positive Psychology and Aging Aspects of Leisure}

So far our reflections were, in a sense, more theoretical. It would now highlight some application possibilities in more practical processes.

As would be practices that could implement a fuller human development? Could be, for example, some that could provide a more human approach, according to the age and abilities/skills, and motivation. In Europe we see in train stations, several posters with proposals for a trip to this transport route: for some people between 60 65 and 70 there is the railway section, with accompanying guides, stretches with light walk, from time to Once a refuge, any entertainment activity. An older age group, plus the guide and smaller and slower walk snippets have the accompaniment of a health team. More age and the presence of a complete team, physician and possibility of rescue form transporting appear more clearly. It means that, depending on the capabilities and the provision in terms of a working age, described above, not only chronological, there are levels where the person can enter and feel welcome and protected.

These possibilities are beginning to also appear on air and sea/river companies with travel agencies that prepare more specific and customized packages for seniors. Alternatively, even the tourism companies, with vans adapted for seniors.

Another attention can be given in health systems, and we are not just talking about queues and special places to meet. We have to take into account that the aging population is growing, with more needs and even requirements. The newest ideas go in the direction of day hospitals, including parking areas, elevators/escalators/chairs and stretchers adapted to the environment, which should be as pleasant as one of the pediatric service area, with its aspects of colors, the largest mobile with better seats and rounded corners, flat system 'sap' text with appropriate size and less fast.

Speaking of movies and books, there are numerous possibility of “clubs of movies”, "book clubs” for discus- 
sions and intergenerational participation and not just bingos and "seven meals a day" as decoys.

If we go to smaller units, such as families, we can and should think of preparing these families or some of its members, more toward the preparation of caregivers in specific courses as PUCRS in Biomedical Gerontology, for example.

Recreation and leisure is also a field to be further explored. We have here, from golf complexes, thalassotherapy (Fernandes \& Fernandes, 2000), with the hot springs, to possibilities of more alternative therapies with salt, fruits and vegetables, different types of water, massage therapy, Pilates, acupuncture, among others. It is usually on a worldwide network, integrated in such a way that people spend seasons between them.

Another point to be considered in Leisure would be clubs, places on beaches, in the mountains with more specific design and architecture, taking into account their adaptations and needs, for example with buoys, ropes, accessibility, lifeguards, shaded areas, stairs/ramps, lifts access to swimming pools, notices to remove hearing aids before entering the water. Leisure clubs that deal with ecology, where there is possibility of diving, there should be special glasses or even swimming goggles with degree or possibility of adjusting his glasses and looser wetsuits, stairs to climb in the saddle animals, and many other special adaptations.

Not to mention great parks, some world in which the advertisement is for children, forgetting that they sometimes go with her grandparents, not necessarily just parents.

\section{In Summary}

We try, in our text, to point out aspects that can answer some of the questions raised by commented scholars and our own concerns; it is in our interest to offer the possibility of a better life and more fully, for a better living in the present and future next, the addressed aging issues.

\section{References}

Adrián, M. H. del C. (1999). Dificultades de aprendizaje y Tercera Edad: Prácticas [Learning Difficulties and the Elderly: Practical]. Madrid: UNED.

Alaphilippe, D., \& Bailly, N. (2014). Psicologia do adulto idoso [Psychology of Elderly]. Lisboa: Piaget.

André, C. (2014). Y no te olvides de ser feliz [And Do Not Forget to Be Happy]. Barcelona: Kairós.

Argimon, I. I. de L., Esteves, C. S., Cerutti, F., Mosquera, J. J. M., \& Stobäus, C. D. (2015) How to Get Better Aging, Bet on Positive Psychology. Psychology, 6, 1855-1860. www.scirp.org/journal/PaperInformation.aspx?PaperID=61061 http://dx.doi.org/10.4236/psych.2015.614182

Carr, W. (1996). Una teoría para la Educación. Hacia uma investigación educativa crítica [A Theory for the Education. Toward a Critical Educational Investigation]. Madrid: Morata.

Damásio, A. (2003). Ao encontro de Espinoza [To Meet Espinosa]. Lisboa: Publicações Europa-América.

de Jesus, S. N., Mosquera, J. J. M., Stobaus, C. D., Sampaio, A., Rezende, M., \& Mascarenhas, S. (2011). Avaliação da Motivação e do Bem/Mal-Estar dos Professores. Estudo comparativo entre Portugal e Brasil [Assessment of Motivation and the Welfare/Malaise of Teachers. Comparative Study between Portugal and Brazil]. Revista Amazônica, 7, 7-18. https://dialnet.unirioja.es/descarga/articulo/3912372.pdf

Dohms, K. P., Lettnin, C. da C., Mendes, A. R., Mosquera, J. J. M., \& Stobäus, C. D. (2014). Affectivity of University Teachers: Personal, Social and Institutional Aspects. Psychology, 5, 1783-1793. http://dx.doi.org/10.4236/psych.2014.515185

Dohms, K. P., Stobäus, C. D., \& Mosquera, J. J. M. (2012). Níveis de Mal/Bem-Estar, Autoimagem e Autoestima e Autorrealização de docentes em uma escola tradicional de Porto Alegre [Levels of Malaise/Wellness, Self-Concept and Self-Esteem and Self-Realization of Teachers in a Traditional School in Porto Alegre]. Série-Estudos (Ucdb), 34, $227-246$. http://www.serie-estudos.ucdb.br/index.php/serie-estudos/article/viewFile/99/55

Fernandes, F. M. V., \& Fernandes, J. V. (2000). Turismo de Saúde e Bem-estar no Mundo [Tourism Health and Wellness in the World]. São Paulo: SENAC.

Fernández-Ballesteros, R. (Ed..). (2009a). Psicogerontología. Perspectivas europeas [Psychogerontology. European Perspectives]. Madrid: Pirámide.

Fernández-Balleteros, R. (2009b). Envejecimiento activo. Contribuciones de la Psicología [Active Aging. Contributions of Psychology]. Madrid: Pirámide.

Fontoura, C. F., Stobäus, C. D., \& Mosquera, J. J. M. (2011). O Docente como modelo de relações afetivas motivadoras para aprendizagens positivas [The Teacher as Motivating Affective Relations Model for Positive Learning]. La Salle (Canoas), 
16, 73-88.

http://biblioteca.unilasalle.edu.br/docs_online/artigos/revista_la_salle/Aguardando_liberacao_direitos_autorais/2011_v16 n1/cffontoura.pdf

Fragoso, V., \& Chaves, M. (2012). Educação emocional para Seniores [Emotional Education for Seniors]. Viseu: Psico \& Soma.

Hué, C. (2012). Bienestar docente y pensamiento emocional [Teacher Welfare and Emotional Thinking]. Revista Fuentes, 12, 47-68. http://institucional.us.es/fuentes/gestor/apartados_revista/pdf/monografico/cakpaain.pdf

Lemaire, P., \& Bherer, L. (2012). Psicologia do envelhecimento. Uma perspectiva cognitiva [Aging Psychology. A Cognitive Perspective]. Lisboa: Piaget.

Lima, M. L., Bernardes, S. F., \& Marques, S. (2014). Psicologia da Saúde. Investigação e Intervenção em Portugal [Health Psychology. Research and Intervention in Portugal]. Lisboa: Edições Sílabo.

Marchand, H. (2005). Psicologia do Adulto e do Idoso [Psychology of Adult and Elderly]. Coimbra: Quarteto.

Mosquera, J. J. M., \& Stobäus, C. D. (1984). Educação para a Saúde. Desafios para sociedades em desenvolvimento [Health Education. Challenges for Developing Societies] (2rd ed.). Porto Alegre: Luzzatto.

Mosquera, J. J. M., \& Stobäus, C. D. (2006a). Auto-Imagem, Auto-Estima e Auto-Realização: Qualidade de Vida na Universidade [Self-Image, Self-Esteem and Self-Realization: Quality of Life at the University]. Psicologia, Saúde \& Doenças, 7, 83-88. http://www.scielo.mec.pt/scielo.php?script=sci_arttext\&pid=S1645-00862006000100006

Mosquera, J. J. M., \& Stobäus, C. D. (2006b). Afetividade: A manifestação dos sentimentos na Educação [Affectivity: The Manifestation of Feelings in Education]. Revista Educação (Pucrs. Online), 29, 123-133. http://revistaseletronicas.pucrs.br/ojs/index.php/faced/article/viewFile/438/334

Mosquera, J. J. M., \& Stobäus, C. D. (2012). Filosofíade la Educación-reflexiones para docentes [Philosophy of EducationReflections for Teachers]. Porto Alegre: EdiPUCRS.

Mosquera, J. J. M., Stobäus, C. D., \& Huertas, J. A. (2015). Teachers in Post-Modern Era: Narratives of Teaching Subjectivity. Creative Education, 6, 945-952. http://www.scirp.org/journal/PaperDownload.aspx?paperID=57271 http://dx.doi.org/10.4236/ce.2015.610096

Mosquera, J. J. M., Stobäus, C. D., \& Timm, E. Z. (2009). O Professor e o Cuidado de si: Perspectivando a Própria Vida como Uma Obra de Arte. Por Que Não? Ciência em Movimento, 11, 47-53. www.metodista.br/revistas/revistas-ipa/index.php/EDH/article/viewFile/115/80 http://dx.doi.org/10.15602/1983-9480/cmedh.v11n22p47-53

Mosquera, J. J. M., Stobäus, C. D., de Jesus, S. N., \& Hermínio, C. H. (2006). Universidade, Auto-imagem, auto-estima e auto-realização [University, Self-Image, Self-Esteem and Self-Realization]. UNIrevista (UNISINOS), 1, 1-13. https://www.researchgate.net/profile/Saul_Jesus/publication/28083197_Auto-imagem_auto-estima_e_auto-realizacao_na_ universidade/links/0046351c0132508ad7000000.pdf

Neri, A. L. (2006). O legado de Paul B. Baltes à Psicologia do Desenvolvimento e do Envelhecimento. Temas em Psicologia, 14, 17-34. http://pepsic.bvsalud.org/scielo.php?pid=S1413-389X2006000100005\&script=sci_abstract

Papalia, D. E., \& Feldman, R. C. (2013). Desenvolvimento Humano [Human Development] (12th ed.). Porto Alegre: AMGH.

Patrocinio, W. P., \& da Côrte Pereira, B. P. (2013). Efeitos da educação em saúde sobre atitudes de idosos e sua contribuição para a educação gerontológica [Health Education Effects on Attitudes of Older People and Their Contribution to Gerontological Education]. Trabalho, Educação e Saúde, 11. http://dx.doi.org/10.1590/S1981-77462013000200007

Seligman, M. E. P., Steen, T. A., Park, N., \& Peterson, C. (2005). Positive Psychology Progress. Empirical Validation of Interventions. American Psychologist, 60, 410-421. http://www.psykologtidsskriftet.no/pdf/2005/874-884.pdf http://dx.doi.org/10.1037/0003-066X.60.5.410

Snyder, C. R., \& Lopez, S. J. (2009). Psicologia Positiva: Uma abordagem científica e prática das qualidades humanas [Positive Psychology: A Scientific and Practical Approach of Human Qualities]. Porto Alegre: Artmed.

Sousa, C. (2006). Educação para a resiliência [Education for Resilience]. Município de Tavira: Tavira-PT.

Sousa, C., \& Rodrigues-Miranda, F. P. (2015). Envelhecimento e Educação para Resiliência no Idoso [Aging and Education for Resilience in the Elderly]. Educação \& Realidade, 40, 33-51.

http://www.seer.ufrgs.br/index.php/educacaoerealidade/article/view/45562/32227

http://dx.doi.org/10.1590/2175-623645562

Sousa, C., Miranda, F., Lara Nieto, M. C., \& Dores, R. (2014). Educação para a resiliência [Education for Resilience]. Conhecimento \& Diversidade, 6, 26-40.

http://www.revistas.unilasalle.edu.br/index.php/conhecimento diversidade/article/view/1740/1145

Stobäus, C. D., \& Mosquera, J. J. M. (2014). Positive Psychology and Emotional Schedule: Building Healthy Self-Con- 
struction. Psychology, 5, 533-540. http://www.scirp.org/journal/PaperInformation.aspx?PaperID=45269 http://dx.doi.org/10.4236/psych.2014.56063

Stobäus, C. D., Mosquera, J. J. M., \& Santos, B. S. (2007). Grupo de Pesquisa mal-estar e bem-estar na docência [Research Group Malaise and Wellbeing in Teaching]. Educação, XIX, 259-272.

http://revistaseletronicas.pucrs.br/ojs/index.php/faced/article/viewFile/3562/2787

Timm, E. Z., Mosquera, J. J. M., \& Stobäus, C. D. (2008). Resiliência: Necessidade e Possibilidade de Problematização em Contextos de docência [Resilience: The Need and Possibility of Questioning in Teaching Contexts]. Revista Educação (PUCRS. Online), 31, 39-45. http://www.redalyc.org/articulo.oa?id=84806406

UNESCO (1996/2010). Educação um tesouro a descobrir [Learning the Treasure within]. Paris: UNESCO. http://unesdoc.unesco.org/images/0010/001095/109590por.pdf

Zacharias, J., Mendes, A. R., da Lettnin, C. C., Dohms, K. P., Mosquera, J. J. M., \& Stobäus, C. D. (2011). Saúde e Educação: do mal-estar ao bem-estar docente [Health and Education: From Malaise to Teaching Wellness]. Revista Educação por Escrito-PUCRS, 2, 16-30.

http://revistaseletronicas.pucrs.br/ojs/index.php/porescrito/article/download/8674/6642

\section{Submit or recommend next manuscript to SCIRP and we will provide best service for you:}

Accepting pre-submission inquiries through Email, Facebook, Linkedin, Twitter, etc A wide selection of journals (inclusive of 9 subjects, more than 200 journals)

Providing a 24-hour high-quality service

User-friendly online submission system

Fair and swift peer-review system

Efficient typesetting and proofreading procedure

Display of the result of downloads and visits, as well as the number of cited articles

Maximum dissemination of your research work

Submit your manuscript at: http://papersubmission.scirp.org/ 